\title{
STUDI KOMPARATIF : REAKSI PASAR MODAL DAN PASAR MODAL SYARIAH TERHADAP KEMENANGAN JOKOWI 2019 (JOKOWI'S EFFECT)
}

\author{
Comparative Study: The Reaction of Stock Market and Islamic Stock Market to The \\ Victory of Jokowi 2019 (Jokowi's Effect)
}

\author{
'Ernawati", ${ }^{2}$ Putri Reno Kemala Sari, ${ }^{3}$ Nova Adhitya Ananda \\ Manajemen, Fakultas Ekonomi dan Bisnis, Universitas \\ Teknologi Sumbawa \\ Jl. Raya Olat Maras, Batu Alang, Moyo Hulu, Kabupaten \\ Sumbawa \\ Email: ernalukman2205@gmail.com
}

\begin{abstract}
Abstrak
Penelitian ini bertujuan untuk mengetahui reaksi pasar modal dan pasar modal syariah terhadap kemenangan Jokowi 2019. Metode analisis yang digunakan adalah uji beda yang dilakukan pada sebelum dan setelah kemenangan Jokowi 2019. Variabel yang digunakan yaitu, rata-rata abnormal return dan rata-rata Trading Volume Activity (TVA) dengan kemenangan Jokowi 2019 sebagai fenomena yang bereaksi terhadap variabel tersebut. Populasi adalah perusahaan-perusahaan yang sahamnya termasuk dalam Indeks LQ45 dan Jakarta Islamic Index yang terdaftar dalam Bursa Efek Indonesia dengan sampel sebanyak 36 perusahaan, yaitu 20 perusahaan yang termasuk dalam Indeks LQ45 dan 16 perusahaan yang termasuk dalam Jakarta Islamic Index. Jenis data yang digunakan adalah data sekunder dan alat analisis yang digunakan adalah SPSS. Hasil analisis yang diperoleh pada rata-rata abnormal return menunjukkan bahwa tidak terdapat perbedaan rata-rata abnormal return antara sebelum dan setelah kemenangan Jokowi 2019 pada Indeks LQ45 tetapi terdapat perbedaan pada Jakarta Islamic Index. Kemudian hasil ananlisis yang diperoleh pada ratarata Trading Volume Activity (TVA) menunjukkan bahwa terdapat perbedaan rata-rata Trading Volume Activity (TVA) antara sebelum dan setelah kemenangan Jokowi 2019 pada Indeks LQ45 dan Jakarta Islamic Index.
\end{abstract}

Kata Kunci : Studi Komparatif, Pasar Modal, Pasar Modal Syariah, Kemenangan Jokowi

\begin{abstract}
This study aims to find out the reaction of stock market and Islamic stock market to the victory of Jokowi 2019. The analyses method was using different test conducted before and after Jokowi's victory. The variables were average abnormal return and average stock trading volume activity with the victory of Jokowi 2019 as a phenomenon that reacts to these variables. The population was companies who are their stock were included in the LQ45 Index and Jakarta Islamic Index which are listed in Indonesia stock exchange with 36 sample companies, where 20 companies are included in the LQ45 Index and 16 companies are included in Jakarta Islamic Index. The data was using secondary data and the analysis tool was using SPSS. The analysis results obtained on the average abnormal return indicates there's no difference in average abnormal return between before and after the victory of Jokowi 2019 on the LQ45 Index, but there's difference on Jakarta Islamic Index. And then the analysis results obtained on average stock trading volume activity between before and after the victory of Jokowi 2019 on the in the LQ45 Index and Jakarta Islamic Index.
\end{abstract}

Keywords : Comparative study, stock market, Islamic Stock Market, The victory of Jokowi

\section{PENDAHULUAN}

Pada tanggal 17 April 2019 Indonesia baru saja melakukan pemilu presiden dan telah ditetapkan oleh KPU bahwa Joko Widodo dan KH.Ma'ruf Amin menjadi calon presiden dan wakil presiden terpilih untuk tahun 2019-2024 pada tanggal 30 Juni 2019 (Fernandes, 2019). Sebagai presiden Republik Indonesia terpilih dalam dua periode yang sebelumnya pada periode 2014-2019, kini Joko Widodo kembali menjadi presiden terpilih pada pemilu 2019 periode 2019-2024 (MKRI, 2019). Hal yang menarik dari sosok Joko Widodo adalah calon presiden terpilih yang mempunyai rekam jejak karir yang luar biasa. Beliau sebelumnya menjabat sebagai walikota Solo lalu menjabat menjadi gubernur DKI Jakarta dan pada tahun 2019 terpilih kembali menjadi presiden dalam dua periode (Iralita, 2015). Hal yang tidak disangka adalah ketika partai PDI-P menetapkan Joko Widodo sebagai bakal calon presiden pada tanggal 19 April 2014, bursa saham menanggapi hal tersebut secara positif dan media 
seperti blomberg.co.id serta kompas menyebut Ionjakan tersebut dengan istilah Jokowi's Effect. Kejadian tersebut menjadi perbincangan hangat oleh para ahli pasar modal (Fiton, 2015). Namun, INDEF (2019) mengatakan bahwa Jokowi's Effect hanya bersifat temporer. Jokowi's Effect pada tahun 2019 ini didukung dengan makro ekonomi Indonesia yang sedang positif, mulai dari neraca perdagangan pada Maret 2019 yang surplus dan inflasi yang rendah. Media seperti DetikFinance juga menambahkan bahwa Jokowi's Effect pada tahun 2019 ini terganjal kondisi negatif dari kondisi ekonomi dunia, salah satunya perang dagang antara China dan AS. Namun, jika Jokowi-Ma'ruf bisa mengeluarkan kebijakan yang meredam dampak negatif tersebut, maka tidak menutup kemungkinan bahwa Jokowi's Effect ini akan terjadi kembali pada tahun 2019. Efek kemenangan Jokowi dapat dilihat pada gambar bursa saham Indeks LQ45 dibawah ini :

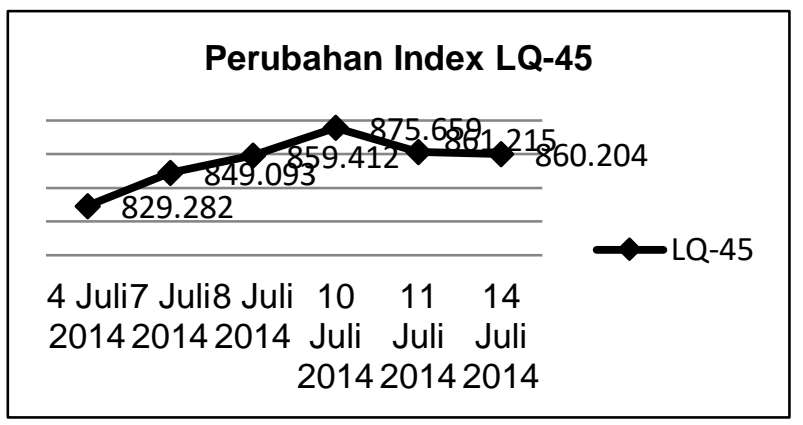

Sumber : (Hutami, 2015)

Gambar 1.1 Indeks Saham LQ45 (4-14 Juli 2014)

Pada gambar 1.1. dalam penelitian Hutami (2015) menunjukan bahwa saham Indeks LQ45 mengalami peningkatan selama 3 hari sebelum terjadi peristiwa pemilu presiden 9 Juli 2014, yaitu pada tanggal 4 Juli 2014 ke tanggal 8 Juli 2014 terjadi peningkatan sebesar 30.130 poin menjadi 859.412 poin. Sedangkan 3 hari terakhir setelah terjadinya peristiwa pemilu presiden, terjadi cukup banyak fluktuasi yaitu pada tanggal 10 Juli 2014 mengalami peningkatan yaitu sebesar 16.247 poin menjadi 875.659 poin.

Reaksi pasar modal akibat peristiwa pemilu presiden dapat dilakukan dengan mengamati pergerakan rata-rata abnormal return pada periode peristiwa (Pratama, et al. 2015). Seperti yang dapat dilihat pada gambar perubahan rata-rata abnormal return saham Indeks LQ45 dibawah ini:

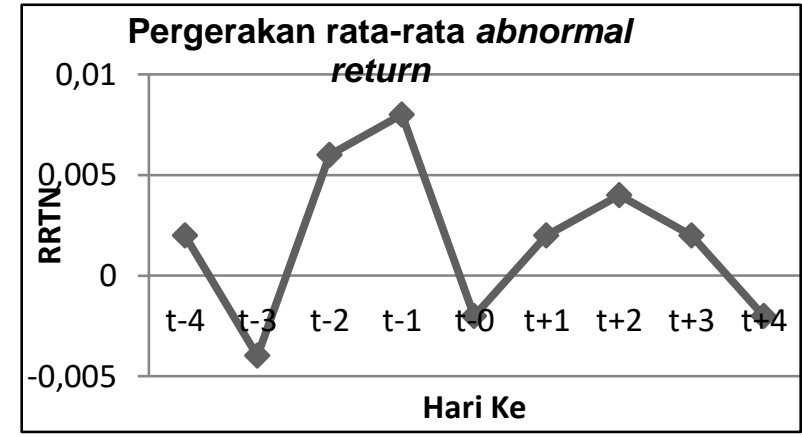

Keterangan :

Sumber :(Pratama, et al. 2015)

$\mathrm{t}-:$ : Hari sebelum peristiwa

$t+:$ Hari setelah peristiwa t-0: Peristiwa

\section{Gambar 1.2 Pergerakan rata-rata abnormal} return saham Indeks LQ45 2014

Pada gambar 1.2. pergerakan abnormal return yang terjadi selama periode peristiwa memiliki dua arah, yaitu positif dan negatif. Gambar 1.2, menunjukan adanya pergerakan abnormal return yang bervariasi saat terjadi peristiwa pelantikan Joko Widodo sebagai presiden Indonesia ke-7. Dari grafik tersebut dapat dilihat bahwa sebelum periode peristiwa pada t-1 ditemukan adanya abnormal return positif paling tinggi, sedangkan pada t-3 ditemukan adanya abnormal return paling rendah pada periode peristiwa, dan pada hari ke to atau saat pelantikan Joko Widodo sebagai presiden Indonesia ke-7 (dilantik pada tahun 2019) didapatkan abnormal return yang negatif (Pratama, et al. 2015).

Selain abnormal return, reaksi pasar di pasar modal juga dapat dilihat melalui volume perdagangan saham yang dapat diukur menggunakan Trading Volume Activity (TVA). Volume perdagangan saham Indeks LQ45 sebagai berikut :

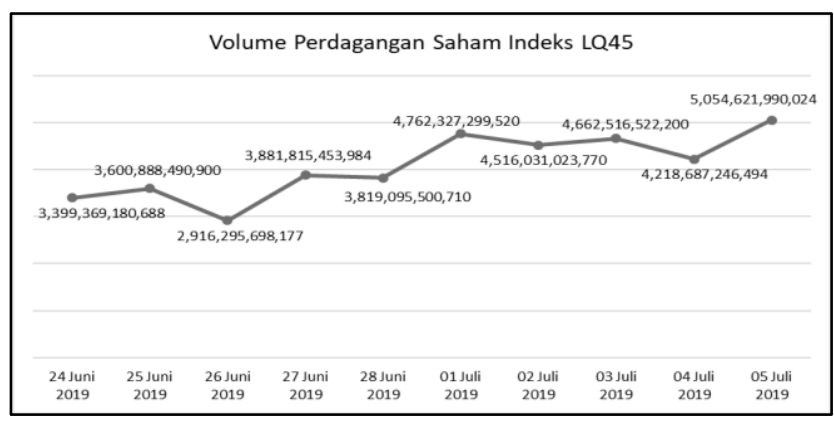

Gambar 1.3 Volume Perdagangan Saham Indeks LQ45 2019

Sumber: Investing.com data diolah peneliti

Pada gambar 1.3. pergerakan volume perdagangan saham Indeks LQ45 selama periode penelitian yaitu 23 Juni sampai dengan 7 Juli 2019. Gambar 1.3. menampilkan perdagangan yang dimulai pada tanggal 24 Juni sampai dengan 7 Juli 2019, karena pada tanggal tersebut merupakan hari dimana efek diperdagangkan atau merupakan hari 
bursa. Pada gambar 1.3. menunjukkan bahwa terdapat peningkatan volume perdagangan saham pada periode setelah kemenangan Jokowi 2019. Peningkatan dapat dilihat pada tanggal 1 Juli 2019 sampai dengan 5 Juli 2019. Peningkatan yang signifikan terjadi pada tanggal 1 Juli dan 5 Juli 2019.

Dalam debat kelima pilpres 2019 pada sabtu 13 april 2019 yang merupakan debat terakhir dan mengangkat tema ekonomi dan kesejahteraan sosial, keuangan, investasi, serta industri. Pasangan Jokowi-Ma'ruf menjanjikan akan membentuk Badan Pengembangan Ekonomi Syariah yang digunakan untuk memajukan produk syariah dalam negeri (debat pilpres, 2019). Tidak hanya produk-produk syariah yang akan dikembangkan tetapi juga perbankan syariah, asuransi syariah dan pasar modal syariah juga akan dikembangkan. Pangsa pasar syariah saat ini masih $5,70 \%$ dari potensi yang dimiliki saat ini yaitu 444,43 triliun rupiah (OJK, 2018). Pemerintah berupaya menggenjot pangsa pasar syariah dengan membentuk Komite Nasional Keuangan Syariah (KNKS) yang diketuai oleh presiden sendiri. Pembentukan komite ini bertujuan agar terjadi percepatan dan mencapai target potensi yang dicanangkan (Bappenas, 2017).

Berdasarkan fenomena tersebut dapat dicermati bahwa pasar modal dan pasar modal syariah akan bereaksi jika terjadi suatu peristiwa yang mempengaruhi kondisi suatu negara. Menurut Alkaff (2010) peristiwa-peristiwa politik merupakan salah satu bagian dari lingkungan non ekonomi yang dapat berpengaruh pada kondisi pasar modal, karena dinamika situasi politik pada dasarnya juga berkaitan dengan stabilitas perekonomian suatu negara.

Pasar modal yang akan diuji kandungan informasinya adalah Indeks LQ45. Indeks LQ45 adalah indeks yang mengukur performa harga dari 45 saham-saham yang memiliki likuiditas tinggi dan kapitalisasi pasar besar serta didukung oleh fundamental perusahaan yang baik (IDX, 2019). Pasar modal syariah yang akan diuji kandungan informasinya adalah Jakarta Islamic Index yang merupakan indeks yang mengukur performa dari 30 saham-saham syariah yang memiliki kinerja keuangan yang baik dan likuditas transaksi yang tinggi (IDX, 2019).

Oleh karena itu, maka peneliti ingin melakukan penelitian mengenai reaksi pasar modal dan pasar modal syariah terhadap kemenangan Jokowi 2019 dengan judul yang diambil dalam penelitian ini adalah "Studi

Komparatif : Reaksi Pasar Modal dan Pasar Modal Syariah Terhadap Kemenangan Jokowi 2019 (Jokowi's Effect).

\section{RUMUSAN MASALAH}

1. Apakah terdapat perbedaan rata-rata abnormal return saham sebelum dan setelah kemenangan Jokowi 2019 pada Indeks LQ45?

2. Apakah terdapat perbedaan rata-rata abnormal return saham sebelum dan setelah kemenangan Jokowi 2019 pada Jakarta Islamic Index?

3. Apakah terdapat perbedaan rata-rata Trading Volume Activity (TVA) sebelum dan setelah kemenangan Jokowi 2019 pada Indeks LQ45?

4. Apakah terdapat perbedaan rata-rata Trading Volume Activity (TVA) sebelum dan setelah kemenangan Jokowi 2019 pada Jakarta Islamic Index?

\section{HIPOTESIS PENELITIAN}

Dalam penelitian Imelda dan Anggraeni (2014) menyatakan bahwa terdapat perbedaan rata-rata abnormal return secara signifikan sebelum dan sesudah peristiwa pemilihan presiden tahun 2004. Berdasarkan teori dan hasil penelitian sebelumnya, sehingga dapat disimpulkan hipotesis sebagai berikut:

H1: Terdapat perbedaan rata-rata abnormal return saham sebelum dan setelah kemenangan Jokowi 2019 pada Indeks LQ45

$\mathrm{H} 2$ : Terdapat perbedaan rata-rata abnormal return saham sebelum dan setelah kemenangan Jokowi 2019 pada Jakarta Islamic Index

Dalam penelitian Sihotang dan Mekel (2015) yang melakukan studi pada perusahaan konstruksi, infrastruktur dan utilitas Pada BEI, Jakarta, menyatakan bahwa terdapat perbedaan yang signifikan antara Trading Volume Activity (TVA) sebelum dan sesudah pemilu presiden. Berdasarkan teori dan hasil penelitian sebelumnya, sehingga dapat disimpulkan hipotesis sebagai berikut:

H3: Terdapat perbedaan rata-rata Trading Volume Activity (TVA) sebelum dan setelah kemenangan Jokowi 2019 pada Indeks LQ45

H4: Terdapat perbedaan rata-rata Trading Volume Activity (TVA) sebelum dan setelah kemenangan Jokowi 2019 pada Jakarta Islamic Index

\section{DEFINISI OPERASIONAL}

\section{Abnormal Return}

Abnormal return atau return tak normal adalah selisih antara return sesungguhnya yang terjadi dengan return ekspektasi. Abnormal return dihitung dari periode 7 hari sebelum dan 7 hari setelah peristiwa (Harahap, 2012). 
a. Perhitungan Expected Return

Rumus perhitungan expected return sebagai berikut (Jogiyanto, 2014) :

$$
E[R i, t]=R m t
$$

Keterangan:

$\begin{array}{ll}\mathrm{E}[\mathrm{Ri}, \mathrm{t}] & =\text { Expected Return } \\ \mathrm{Rmt} & =\text { Return pasar pada } \\ & \text { periode } \mathrm{t}\end{array}$

b. Perhitungan Actual Return

Tandelilin (2010) merumuskan actual return sebagai berikut :

$$
\boldsymbol{R}_{i t=\frac{P_{i t}-P_{i t-1}}{P_{i t-1}}}
$$

$$
\begin{array}{ll}
\text { Keterangan: } & \\
R_{i t} & =\text { Return aktual saham } \mathrm{i} \\
& \text { pada hari } \mathrm{t} \\
P_{i t} & =\text { Harga saham i pada hari } \\
\mathrm{t} & \\
P_{i t-1} & =\text { Harga saham i pada hari } \\
\mathrm{t}-1 &
\end{array}
$$

\section{c. Perhitungan Abnormal Return}

Menurut Jogiyanto (2014), abnormal return dapat dihitung menggunakan rumus :

$$
R T N i, t=R i, t-E(R i, t)
$$

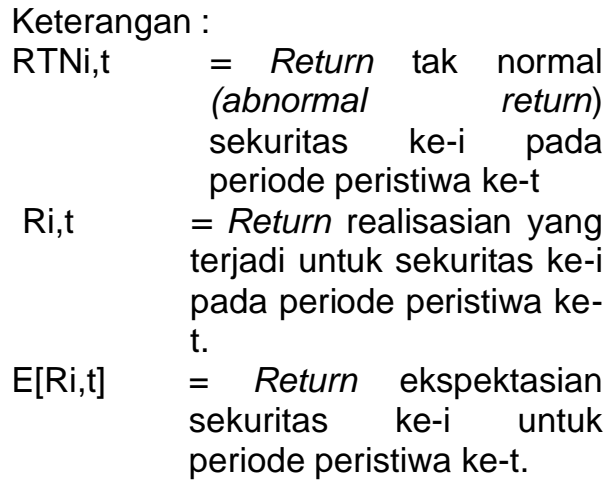

2. Aktivitas Volume Perdagangan (Trading Volume Activity)

$$
\text { Trading Volume Activity (TVA) }
$$

merupakan instrumen yang dapat digunakan untuk melihat reaksi pasar modal terhadap informasi melalui parameter perubahan volume perdagangan saham (Purba, 2017).
Husnan, et al (2017) merumuskan Trading Volume Activity (TVA) sebagai berikut :

$$
\mathrm{TVA}=\frac{\sum \text { saham } \mathrm{i} \text { ditransaksikan pada hari ke } \mathrm{t}}{\sum \text { saham i yang beredar }}
$$

\section{METODE PENELITIAN}

Jenis penelitian dalam penelitian ini adalah penelitian kuantitaif. Penelitian ini mengunakan metode studi peristiwa (event study) politik pemilihan umum persiden 2019 yang dimenangkan oleh Jokowi. Dalam penelitian ini akan menguji apakah pasar bereaksi dengan adanya peristiwa politik tersebut, khususnya pada Indeks LQ45 dan Jakarta Islamic Index.

\section{TEKNIK ANALISIS DATA}

Teknik analisis yang digunakan dalam penelitian ini adalah menggunakan teknik analisis event study, statistik deskriptif, uji normalitas, uji beda (t-test) dengan dua metode, yaitu : jika data berdistribusi normal maka digunakan uji paired sample t-test, jika data tidak berdistribusi normal maka digunakan uji wilcoxon.

\section{HASIL DAN PEMBAHASAN}

\section{Hasil Uji Statistik Deskriptif}

Statistik deksriptif digunakan untuk mengetahui nilai minimum, maximum, mean, dan standar deviasi dari masing-masing variabel.

\section{Uji Normalitas}

Uji normalitas bertujuan untuk menguji apakah dalam model regresi variabel terikat, variabel bebas atau keduanya mempunyai distribusi normal atau tidak. Uji normalitas pada penelitian ini menggunakan Kolmogorov Smirnov (K-S). Pengukuran yang digunakan adalah dengan membandingkan nilai Asymp. Sig (2-tailed) dengan nilai yang ditentukan sebesar $5 \%$. Apabila nilai Asymp. Sig (2-tailed) lebih besar dari 0,05 maka dapat disimpulkan bahwa data tersebut berdistribusi normal. Hasil iji normalitas yang menggunakan uji Kolmogorov Smirnov didapatkan hasil data berdistribusi normal pada rata-rata abnormal return sebelum dan setelah kemenangan Jokowi 2019 pada Indeks LQ45 dan Jakarta Islamic Index. Sedangkan didapatkan hasil data yang tidak berdistribusi normal pada rata-rata Trading Volume Activity (TVA) pada Indeks LQ45 dan Jakarta Islamic Index. 


\section{Uji Beda (t-test)}

Uji beda ( $t$-test) dilakukan dengan cara membandingkan antara dua nilai rata-rata dengan standar error dari perbedaan rata-rata dua sampel. Tujuan uji beda $t$-test adalah membandingkan rata-rata dua sampel yang berhubungan mempunyai nilai yang sama ataukah tidak (Ghozali, 2011). Dalam penelitian ini menggunakan uji beda (paired samples $t$ test) untuk data yang terdistribusi normal dan uji wilcoxon untuk data yang tidak berdistribusi normal. Pengambilan keputusan pada uji ini dilakukan dengan membandingkan nilai sig. (2tailed) dengan tingkat signifikansi $\alpha 5 \%$. Jika nilai sig. (2-tailed) lebih kecil $<$ dari nilai signifikansi $\alpha 5 \%$ maka dinyatakan terdapat perbedaan. Jika nilai sig. (2-tailed) lebih besar $>$ dari nilai signifikansi a 5\% maka dinyatakan tidak terdapat perbedaan. Berdasarkan hasil uji beda rata-rata abnormal return pada Indeks LQ45 yang diuji menggunakan uji paired sample t-test didapatkan nilai sig. (2-tailed) sebesar 0,215 lebih besar $>$ dari nilai signifikansi a 0,05 maka dapat diambil keputusan bahwa hipotesis ditolak dan hasil uji beda rata-rata abnormal return pada Jakarta Islamic Index didapatkan nilai sig. (2-tailed) sebesar 0,027 lebih kecil < dari nilai signifikansi a 0,05 maka dapat diambil keputusan bahwa hipotesis diterima. Hasil uji beda rata-rata Trading Volume Activity (TVA) pada Indeks LQ45 yang diuji menggunakan uji wilcoxon didapatkan nilai sig. (2-tailed) sebesar 0,003 lebih kecil < dari nilai signifikansi a 0,05 maka dapat diambil keputusan bahwa hipotesis diterima dan hasil uji beda rata-rata Trading Volume Activity (TVA) pada Jakarta Islamic Index didapatkan nilai sig. (2-tailed) sebesar 0,002 lebih kecil < dari nilai signifikansi a 0,05 maka dapat diambil keputusan bahwa hipotesis diterima.

\section{PEMBAHASAN}

\section{Abnormal return}

Berdasarkan hasil pengujian hipotesis pertama $(\mathrm{H} 1)$ yang diuji menggunakan uji paired samples $t$-test menunjukkan bahwa tidak terdapat perbedaan rata-rata abnormal return sebelum dan setelah kemenangan Jokowi 2019 pada Indeks LQ45 atau dengan kata lain bahwa hipotesis pertama (H1) ditolak. Hasil ini dapat diinterpretasikan bahwa peristiwa kemenangan Jokowi 2019 dianggap sebagai bad news oleh para pelaku pasar modal. Selain itu, tidak adanya perbedaan rata-rata abnormal return ini diakibatkan oleh beredarnya berita debat pilpres pasangan calon presiden dan wakil presiden 2019. Dalam debat tersebut, pasangan Jokowi-Ma'ruf mengatakan bahwa akan meningkatkan panggsa pasar syariah di Indonesia yang masih berada pada posisi $5,80 \%$. Hal ini menyebabkan para investor beranggapan bahwa dengan menanamkan sahamnya pada saham syariah lebih menguntungkan dibandingkan pada saham konvenisonal, sehingga adanya perpindahan investor dari saham konvensonal ke saham syariah. Hal ini didukung oleh Puspitaningtyas (2013) yang menyatakan bahwa perilaku investor sangat dipengaruhi oleh infomasi yang diterima. Sebab, informasi adalah bersifat individu. Artinya, individu mungkin akan memberikan reaksi yang berbeda terhadap sumber informasi yang sama. Hal ini menunjukkan bahwa individu menerima informasi dan merevisi keyakinan secara berurutan dalam proses berkelanjutan melalui penerimaan informasi yang terkandung dalam laporan keuangan dan juga dari sumber informasi lain seperti media, dan pengumuman lain yang dapat mempengaruhi keputusannya. Ketertarikan investor pada saham syariah menyebabkan sedikitnya permintaan saham pada saham konvensional. Hal ini dapat menyebabkan penurunan harga saham. Penurunan harga saham akan berdampak pada return saham yang akan diterima investor. Sehingga tidak adanya abnormal return, karena return ekspektasi lebih tinggi dibandingkan return realisasi. Penelitian ini didukung oleh penelitian Sihotang dan Mekel (2015), Chan et al. (2014), Luhur (2010), Supragita (2011) dan Wardhani (2012) yang menyatakan bahwa tidak terdapat perbedaan rata-rata abnormal return baik sebelum maupun setelah peristiwa.

Berdasarkan hasil pengujian hipotesis kedua (H2) yang diuji menggunakan uji paired samples $t$ test menunjukkan bahwa terdapat perbedaan ratarata abnormal return sebelum dan setelah kemenangan Jokowi 2019 pada Jakarta Islamic Index atau dengan kata lain bahwa hipotesis kedua (H2) diterima. Hasil ini dapat diinterpretasikan bahwa peristiwa kemenangan Jokowi 2019 mempengaruhi rata-rata abnormal return pada perusahaan yang terdaftar dalam Jakarta Islamic Index. Hal ini diakibatkaan karena peristiwa kemenangan Jokowi 2019 mengandung sebuah informasi yang berarti bagi pasar dan pasar menanggapi hal tersebut dengan cepat. Selain itu adanya perbedaan rata-rata abnormal return pada Jakarta Islamic Index ini disebabkan adanya respon yang cepat dari pasar dengan beredarnya berita saat debat pilpres kelima bahwa pasangan JokowiMa'ruf yang mengatakan akan meningkatkan pangsa pasar syariah di Indonesia. Hal tersebut dianggap sebagai good news oleh para pelaku pasar modal dengan mempercayai regulasi-regulasi yang akan diberlakukan pada masa jabatan JokowiMa'ruf. Hal ini menyebabkan terjadinya peningkatan 
harga saham pada perusahaan yang terdaftar dalam Jakarta Isalmic Index sehingga mengakibatkan adanya abnormal return. Penelitian ini didukung oleh penelitian Imelda et al. (2014), Prabandari (2015), Suwaryo (2008), Katti (2018) dan Rofiqi et al. (2018) yang menyatakan bahwa terdapat perbedaan ratarata abnormal return baik sebelum maupun setelah peristiwa.

\section{Trading Volume Activity (TVA)}

Berdasarkan hasil pengujian hipotesis ketiga $(\mathrm{H} 3)$ yang diuji menggunakan uji wilcoxon menunjukkan bahwa terdapat perbedaan rata-rata Trading Volume Activity (TVA) sebelum dan setelah kemenangan Jokowi 2019 pada Indeks LQ45 atau dengan kata lain bahwa hipotesis ketiga (H3) diterima. Hasil ini dapat diinterpretasikan bahwa peristiwa kemenangan Jokowi 2019 berpengaruh terhadap Trading Volume Activity (TVA) pada Indeks LQ45. Hal ini menunjukkan bahwa kemenangan Jokowi 2019 memiliki infromasi yang berarti bagi investor sehingga menyebabkan Trading Volume Activity (TVA) yang meningkat di pasar modal. Karena investor akan beranggapan bahwa dengan melakukan aksi jual maupun beli akan memberikan keuntungan bagi mereka. Namun, hasil ini berbanding terbalik dengan hasil ratarata abnormal return yang dihasilkan pada Indeks LQ45. Hal ini mengindikasikan, sekalipun Trading Volume Activity (TVA) meningkat dan biasanya para investor berkeinginan untuk membeli dan/atau menjual sesuai dengan harga dan jumlah yang diinginkan, namun tidaklah selalu memperoleh keuntungan sesuai dengan yang diharapkan. Oleh sebab itu, dalam penelitian ini ditemukan adanya perbedaan rata-rata Trading Volume Activity (TVA) pada Indeks LQ45, namun tidak dibarengi dengan adanya perbedaan rata-rata abnormal return. Penelitian ini didukung oleh penelitian Sigotang dan Mekel (2015) dan Nurheriyani (2015) yang menyatakan bahwa terdapat perbedaan rata-rata Trading Volume Activity (TVA) sebelum dan setelah peristiwa.

Berdasarkan hasil pengujian hipotesis keempat $(\mathrm{H} 4)$ yang diuji menggunakan uji wilcoxon menunjukkan bahwa terdapat perbedaan rata-rata Trading Volume Activity (TVA) sebelum dan setelah kemenangan Jokowi 2019 pada Indeks LQ45 atau dengan kata lain bahwa hipotesis keempat (H4) diterima. Hal ini menunjukkan bahwa terdapat perbedaan rata-rata Trading Volume Activity (TVA) dan setelah kemenangan Jokowi 2019 pada Jakarta Islamic Index. Hasil ini dapat diinterpretasikan bahwa peristiwa kemenangan
Jokowi 2019 berpengaruh terhadap Trading Volume Activity (TVA) pada Jakarta Islamic Index. Hal ini menunjukkan bahwa kemenangan Jokowi 2019 memiliki infromasi yang berarti bagi investor sehingga menyebabkan Trading Volume Activity (TVA) yang meningkat di pasar modal, karena investor akan beranggapan bahwa dengan melakukan aksi jual maupun beli akan memberikan keuntungan bagi mereka. Hasil ini sebanding dengan hasil rata-rata abnormal return yang dihasilkan pada Jakarta Islamic Index. Hal ini menunjukkan bahwa tingginya rata-rata Trading Volume Activity (TVA) diakibatkan meningkatnya harga saham, sehingga investor berkeinginan untuk melakukan aksi jual maupun beli dengan pengharapan penerimaan return saham yang tinggi yang tercermin pada rata-rata abnormal return. Penelitian ini didukung oleh penelitian Hartono dan Febdwi (2015) dan Fiton (2015) yang menyatakan bahwa terdapat perbedaan rata-rata Trading Volume Activity (TVA) sebelum dan setelah peristiwa.

3. Berdasarkan hasil penelitian yang menguji perbedaan rata-rata abnormal return sebelum dan setelah serta perbedaan rata-rata Trading Volume Activity (TVA) sebelum dan setelah kemenangan Jokowi 2019. Maka dapat dilihat pasar modal yang paling bereaksi terhadap kemenangan Jokowi 2019 adalah pasar modal syariah yaitu Jakarta Islamic Index. Hal ini dapat dilihat dari hasil uji beda rata-rata abnormal return dan hasil uji beda rata-rata Trading Volume Activity (TVA) yang berbanding lurus. Hal ini diakibatkan oleh adanya wacana regulasi yang akan diterapkan oleh pasangan Jokowi-Ma'ruf pada masa jabatan yaitu pasangan Jokowi-Ma'ruf akan meningkatkan pangsa pasar syariah. Maka hal ini dianggap sebagai good news oleh para pelaku pasar modal sehingga mengakibatkan para pelaku pasar modal melakukan transaksi di pasar modal.

\section{PENUTUP}

\section{Kesimpulan}

1. Hasil pengujian hipotesis pertama $\left(\mathrm{H}_{1}\right)$ menunjukkan bahwa tidak terdapat perbedaan rata-rata abnormal return sebelum dan setelah kemenangan Jokowi 2019 pada Indeks LQ45. Hal tersebut dibuktikan melalui hasil perhitungan uji beda paired samples t-test yang membuktikan bahwa tidak terdapat perbedaan rata-rata abnormal return sebelum dan setelah kemenangan Jokowi 2019, yaitu dimana rata-rata abnormal return sebelum adalah sebesar $-0,00340$ dan rata-rata abnormal return setelah adalah sebesar $-0,00030$. 
2. Hasil pengujian hipotesis kedua (H2) menunjukkan bahawa terdapat perbedaan rata-rata abnormal return sebelum dan setelah kemenangan Jokowi 2019 pada Jakarta Islamic Index. Hal tersebut dibuktikan melalui hasil perhitungan uji beda paired samples t-test yang membuktikan bahwa terdapat perbedaan rata-rata abnormal return sebelum dan setelah kemenangan Jokowi 2019, yaitu dimana rata-rata abnormal return sebelum adalah sebesar $-0,00056$ dan rata-rata abnormal return setelah adalah sebesar 0,00556 .

3. Hasil pengujian hipotesis ketiga $(\mathrm{H} 3)$ menunjukkan bahwa terdapat perbedaan rata-rata Trading Volume Activity (TVA) sebelum dan setelah kemenangan Jokowi 2019 pada Indeks LQ45. Hal tersebut dibuktikan melalui hasil perhitungan uji beda dengan uji wilcoxon yang membuktikan terdapat perbedaan rata-rata Trading Volume Activity (TVA) sebelum dan setelah kemenangan Jokowi 2019, yaitu dimana rata-rata Trading Volume Activity (TVA) sebelum adalah sebesar 0,00155 dan rata-rata Trading Volume Activity (TVA) setelah adalah sebesar 0,00205 .

4. Hasil pengujian hipotesis keempat $(\mathrm{H} 4)$ menunjukkan bahwa terdapat perbedaan rata-rata Trading Volume Activity (TVA) sebelum dan setelah kemenangan Jokowi 2019 pada Jakarta Islamic Index. Hal tersebut dibuktikan melalui hasil perhitungan uji beda dengan uji wilcoxon yang membuktikan bahwa terdapat perbedaan rata-rata Trading Volume Activity (TVA) sebelum dan setelah kemenangan Jokowi 2019, yaitu dimana rata-rata Trading Volume Activity (TVA) sebelum adalah sebesar 0,00166 dan rata-rata Trading Volume Activity (TVA) setelah adalah sebesar 0,00356 .

\section{Saran}

1. Penelitian selanjutnya yang memiliki fokus yang sama mungkin dapat menambahkan sampel penelitian dengan menggunakan seluruh perusahaan yang tercatat di Bursa Efek Indonesia sebagai sampel penelitian. Penambahan sampel penelitian yang lebih besar ini diharapkan agar dapat menghasilkan hasil pengujian yang lebih akurat mengenai pengaruh peristiwa politik terhadap pasar modal Indonesia.

2. Perusahaan harus mengantisipasi kebijakan-kebijakan dan regulasi-regulasi dari pemerintahan yang baru. Kondisi politik juga dapat mempengaruhi kondisi perekonomian dan iklim usaha di suatu negara. Jadi, perusahaan harus mengantisipasinya agar perusahaan tetap stabil dan memiliki daya saing dengan kompetitor lain meskipun setelah pergantian pemimpin negara nanti muncul kebijakan dan regulasi baru dari pemerintah.

3. Investor harus mencermati setiap kejadian-kejadian yang dapat berdampak secara makro karena tidak hanya faktor ekonomi saja yang dapat mempengaruhi harga saham dipasar tetapi faktor non ekonomi juga bisa mempengaruhi pergerakan harga saham di pasar modal. Sebaiknya investor selalu mengamati pergerakan harga saham disekitar peristiwa kemenangan serta mempelajari peristiwa dimasa lampau sebagai acuan untuk melakukan trading.

\section{DAFTAR PUSTAKA}

Alkaff, M. Q. (2010). Pengaruh Pemilihan Presiden RI 2009 Terhadap Harga Saham dan Volume Perdagangan Saham Perusahaan di Bursa Efek Indonesia. Skripsi Fakultas Ekonomi Universitas Pembangunan Nasional Veteran.

Bappenas. (2017). Komite Nasional Keuangan Syariah Untuk Percepatan
Pengembangan Ekonomi dan
Keuangan Syariah Indonesia.
Retrieved September 6, 2019, from
www.bappenas.go.id

Chandra, C. H., Anastasia, N., \& Memarista, G. (2014). Perbedaan Average Abnormal return, Average Trading Volume Activity Sebelum dan Sesudah Pemilu 2004 dan 2009 di Indonesia. Universitas Kristen Petra Surabaya.

DetikFinance. (2019). Drama Pilpres Berakhir, Akankah Jokowi Effect Muncul? Retrieved Oktober 15, 2019, from http://m.detik.com 
Fernandes, A. (2019). politik identitas dalam pemilu 2019 : proyeksi dan efektifitas. centre for strategy and international studies.

Fiton, M. H. (2015). Analisis Pengaruh Pelantikan Kabinet Kerja Joko Widodo pada 27 Oktober Terhadap Reaksi Pasar Saham (Studi Kasus pada Saham yang Terdaftar LQ45 di BEI. Skripsi, Universitas Islam Negeri Maulana Malik Ibrahim Malang.

Ghozali, I. (2011). Aplikasi Analisis Multivariate dengan Program IBM SPSS 19. Semarang: Badan Penerbit Universitas Diponegoro.

Hartono, Y., \& Febdwi, S. (2015). Reaksi Pasar Modal Indonesia Terhadap Peristiwa Politik Dalam Negeri (Studi Kasus Pada Pemilu Presiden Indonesia 2014). Jurnal Program Studi Akuntansi Sekolah Tinggi IImu Ekonomi Pelita Indonesia.

Husnan, S., M.Mamduh, \& Wibowo, A. (2017). Dampak Pengumuman Laporan Keuangan Terhadap Kegiatan Perdagangan Saham dan Variabilitas Tingkat Keuntungan. Vol 05(No 11).

Hutami, R. N. (2015). Abnormal Return dan Trading Volume Activity Sebelum dan Setelah Pemilihan Presiden Secara Langsung 9 Juli 2014 (Studi Kasus Pada Saham LQ-45). Skripsi Universitas Diponegoro Semarang.

IDX, I. S. (2019). Indeks Syariah. Retrieved September 10, 2019, from www.idx: https://www.idx.co.id

IDX, I. S. (2019). Ringkasan Performa Perusahaan LQ45. Retrieved September 15, 2019, from www.idx: https://www.idx.co.id

Imelda, H. S., \& Anggraeni, L. (2014). Abnormal Returns and Trading Volume in the Indonesian Stock Market in Relation to the Presidential Elections in 2004, 2009, and 2014. International Journal of Administrative Science and Organization Institut Pertanian Bogor, Vol 21(No 2), 65-76.
INDEF, I. f. (2019). Jokowi's Effect pada Pilpres 2019. Retrieved Oktober 15, 2019, from indef.or.id: https://indef.or.id

Investing. (2019). Data Historis Indeks IDX LQ45 (JKLQ45)- Investing.com. Retrieved September 23, 2019, from m.id.investing: https://m.id.ivesting.com

Iralita, D. A. (2015). Perilaku Politik Jokowi Sebagai Presiden Dalam 100 Hari.

Jogiyanto. (2014). Teori Portofolio dan Analisis Investasi. Yogyakarta: BPFE.

Katti, S. B. (2018). Pengaruh Peristiwa Politik(Pemilu Presiden dan Pengumuman Susunan Kabinet) Terhadap Saham Sektor Industri di BEI. e-Journal Fakultas Ekonomi Universitas Merdeka Madiun, Vol 01(N0.02).

Luhur, S. (2010). Reaksi Pasar Modal Indonesia Seputar Pemilihan Umum 8 Juli 2009 pada Saham LQ-45. Jurnal Keuangan dan Perbankan, Vol 14(No 2), 249-262.

MKRI, M. K. (2019). Risalah Sidang Perkara Nomor 01/PHPU-PRES/XVII. Jakarta.

Nurheriyani, A. (2015). Analisis Volume Perdagangan dan Abnormal Return Saham Sebelum dan Sesudah Pelantikan Presiden dan Wakil Presiden. Jurnal Ekonomi dan Kewirausahaan, Vol 15, 167-172.

OJK, O. J. (2018). Snapshot Perbankan Syariah indonesia. Retrieved September 6, 2019, from www.ojk.co.id

Prabandari, M. (2015). Dampak Pengumuman Kemenangan Jokowi pada Pemilihan Umum Presiden 2014 Terhadap Abnormal Return Saham LQ 45 di Bursa Efek Indonesia . Skripsi Universitas Negeri Yogyakarta.

Pratama, I. G., Sinarwati, N. K., \& Dharmawan, N. A. (2015). Reaksi Pasar Modal Indonesia Terhadap Peristiwa Politik (Event Study) pada Peristiwa Pelantikan Joko Widodo Sebagai Presiden Republik Indonesia Ke-7). EJournal S1 AK Universitas Pendidikan Ganesha, 3(01).

Purba, T. (2017). Analisis Komparasi Abnormal Return dan Volume Perdagangan Saham Atas Pemberlakuan Peraturan Pemerintah Nomor 1 Tahun 2014. 


\section{Jurnal Riset Bisnis dan Manajemen FEB Unoversitas Sam Ratulangi, Vol 5(No 1), 55-72.}

Rofiki, D., Topowijono, \& Nurlaily, F. (2018). Reaksi Pasar Modal Indonesia Akibat Peristiwa Pemilihan Gubernur DKI Jakarta Putaran II 2017 (Event Study Pada Perusahaan Yang Terdaftar di Indeks LQ45 Periode Februari-Juli 2017). Jurnal Administrasi Bisnis (JAB)/, 62(2). Retrieved from administrasibisnis.studentjournal.ub. ac.id

Sihotang, E. M., \& Mekel, P. A. (2015). Reaksi Pasar Modal Terhadap Pemilihan Umum Presiden Tanggal 9 Juli 2014 di Indonesia. Jurnal EMBA, Vol 3(No 1), Hal 951-960.

Supragita, I. (2011). Reaksi Pasar Modal Atas Peristiwa Pengumuman Pengunduran Diri Menteri Keuangan dari Kabinet Indonesia Bersatu. Suwaryo. (2008). Dampak Pemilu Presiden dan Wakil Presiden Terhadap Abnormal Return Investor. Jurnal Performance, Vol 7(No 2),119. 